routine will be irksome at first. After a few days you will enjoy it if you do not forget the obedienee and etiquette you were taught in your own training-sehool.

Above all, bear in mind that a good nurse is appreciated wherever she goes. You are a representative, and aeeordingly as you sueeed or fail is the eredit or diseredit refleeted on your training-school.

\title{
PRIVATE NURSING IN ITALY
}

By E. N. LA MOTTE

Graduate Johng Hopkins Hospital

IN evcry eity in the United States the attitudc taken by the plysieian towards a nurse graduated from a first-elass hospital is about the same; local eonditions differ, of course, but in the main her position is alike in each, be it Baltimore, Boston, or San Francisco, or in whatever eity she ehooses to establish herself for the pursuit of private nursing. There are those of us, however, who get tired of working in our own particular town, and who think that nursing in a foreign eountry, in a different atmosphere, and amid novel surroundings would be equally profitable and perhaps more diverting, and to them, therefore, this aecount of what an Ameriean nurse will find in pursuit of her profession in Italy may prove useful. It is taken mainly from my own expericnees and from sources of unquestionable authority, and though the seene of my particular work was Florence, one may safely generalize and say that the eonditions here are those that prevail in Rome and throughout Italy gencrally.

Florenee is an inland town in the north of Italy, of great beauty, extreme age, great historical importancc, and as an art eentre it is almost without a peer. The population is about two hundred thousand, ineluding a large eolony of several hundrcd British and American residents who have made it their permancnt home. At first thought it would secm as if an American nurse would be able to find much of her work among this English-speaking population, but, on the contrary, it is quite the reverse - she will find none of it here. The reason for it is simple enoughforeigners who take up their residenee in Italy from whatever eause, economieal or otherwise, beeome soon imbued with the Italian spirit, and as the nursing standard demanded by most Italian physicians is exceedingly low, a nurse or a nun with little or no training in our sense of the word can readily be found who will answer all the requirements of both doctor and patient, and for a sum for whieh no Ameriean nurse would 
care to compete: There are exceptions to this, of course, but for the most part it holds good. Naturally an American nurse could be of no use to an Italian patient, not only for this reason, but also because she cannot speak the language, and thercfore the only class of people among which she could really find work is that great, shifting, transient population known as "tourists."

This is a class which we have not at all in America; there, when we travel it is to get somewhere, to go from one place to another with a definite object, but here in Europe it is different. People are comparatively idle here, time is abundant, and there is so much of interest to see and to do that a great wave of sight-seers or tourists is continually sweeping over the Continent from place to place, and governed in its movements entirely by the climate or the time of year. When such a wave, whose coming is always anticipated and set for a certain date, strikes a particular city or country and floods it with its hundreds of visitors it is called "the season," and "the season" is good or bad entirely from the points of view of those who profit by it. It is during this pcriod, then, which in Florence extends through March, April, May, and part of June, that an American nurse can be kept busy and on her own terms, and for the most part among her own country people; but, naturally, this dependence on a certain time of year for employment makcs nursing rather a precarious sort of business, as except then, or unless she abandons the idea of earning twenty-five dollars a week, she will find her calls few and far between. If one could only follow up this tide of tourists and manage to be in each city or place as it was inundated, one could be reasonably sure of finding pretty constant work, for there is nothing so exhausting as strenuous sight-seeing, and the people who are "doing" Europe for the first and possibly last time in their lives wish to let nothing escape, thereby fitting themselves for a state in which typhoid, pneumonia, or influenza finds them easy prey. As for obvious reasons, however, a nurse cannot be on hand for a round of "seasons," it would be well for her to ascertain beforehand when the season begins in a particular locality and to lay her plans accordingly. It is well also to find out what, if any, portion of the tourist population there is apt to be American, for Americans are the only people who will pay her the accustomed twenty-five dollars a week. A place flooded with English would be useless from a financial point of view.

Competition in the nursing line is great in Italy. It begins perhaps with the young doctors just graduated from the medical schools, and who depend on "nursing" in the early years of their practice for a large part of their income. These young men "nurse" under a regular physician, and are employed from night to night, as the case may be, during 
the critical stages of an acute illness, or after operations, etc., for which they receive from forty to sixty francs (eight dollars to twelve dollars) a night. They are said to be exeellent nurses; they handle patients and move them in bed with grcat skill and dexterity, give medicines, hypodermics, etc., are of considerable moral support to the family, and prevent the chief from having to be called up at night. This method obtains chiefly among the Italians, and in all cases therc is a nurse or a nun on duty likewise. There is nothing about this sort of nursing that a wclltrained nurse could not do, and it is said that the opposition on the part of these young physicians to the introduction of modern hospital trainingschools and their output of competent nurses, which would naturally mean to them the curtailment of a very profitable source of income, is a considerable factor in the general opposition to nurses and trainingschools that has made Italy so lamentably behind the world's progress in this regard.

Pcrhaps the most popular nurses here are the "Little Blue Sisters," or "Blue Nuns," so called because of their habit, a nursing order of Irish and Australian extraction. They are about sixty in number, hospital trained, and some are extremcly competcnt, their degree of capability varying, however, and dependent on the length of time that has been passed in the hospital. Their headquarters are at Fiesole, about three miles out of Florence, and their terms vary from nothing a day up to two dollars and a half, depending entirely on the patient's ability to afford their services. The convent receives the money that they earn. The Italian nuns are very inexpensive, two francs (forty cents) a day, which likewise is not a personal remuneration, but belongs to their order.

There are some Italian nurses too, but thcir number is very limited. They have been trained in Miss Baxter's school at Naples or by Miss Turton in Florence. For their serviees they are paid at the rate of one dollar a day, but if the case is to be a long one arrangements can be made for ninety francs (eighteen dollars) a month. There is a registry here, and on the books are to be found a few nurses of every nationality, -Dutch, Swiss, German, English, etc.,-all more or less thoroughly trained according to our ideas. A nurse whose engagements are made through this registry pays to it five per cent. of her earnings in addition to the initial fee, but for the most part nurses are obtained through the doctors, who keep a list of their names and average charges, whieh are sometimes modified to meet the requirements of individual eases. The rates range from five to twelve and a half francs (one dollar to two dollars and fifty cents) a day, the average being tcn, but the nurse who charges ten francs for her services at other times asks twelve and a half in "the season" and is usually able to obtain it. An American nurse gets 
from twenty-one to twenty-five dollars a week, usually twenty-one, though she can, as a rule, fix her own terms. (There is a pleasing story about a nurse who had a twelve-weeks' case at a pension here at thirty-five dollars a week, but although it is cited quite freely, facts do not seem to support it-certainly it was exceptional, and no one need expect to repeat it.) People who want an American nurse want her badly, and as they are usually Americans, to whom twenty-five dollars a week is the usual thing, such prices do not seem exorbitant, but to an English nurse they are tremendous and grasping beyond all bounds. There are a few English nurses here from the best London hospitals whose top prices are two dollars and a half a day.

From this it will be seen that the field is full of rivals, and when it is remembered that the doctors here are not used to, do not expect, and do not care for well-trained nurses the outlook is not promising. There are, of course, exceptions-modern, up-to-date, progressive men, who realize the value of skilled, intelligent assistance, and these are generally the physicians employed by the travelling American when he falls ill; but, unfortunately for nurses, American patients are sometimes " out of season." If, then, one wishes to find herself busy at other times than the spring of the year, she must bring her prices down to those asked by nurses, and good ones too, of other nationalities-and this is a hard thing to do. I have had two or three English nurses say to me, "Five pounds a week! Oh, but isn't that rather hard on the poor patients?" Well, of course, that is one way of looking at it. On the other hand, I learned that a patient who was willing to pay two dollars a day (or less) frequently exacted sleepless nights, wearing days, and a general surrender of vitality on the part of the poor nurse. I had an English patient once in a emall private hospital. When she wanted to brush her teeth or have any homely office performed for her she insisted on having one of the servant nurses of the establishment to wait on her; when she wondered whether it would be harmful to lie on her side (she had pleurisy) she would send for the doctor and ask his opinion. A nurse of my calibre she could not understand and had no use for $\rightarrow$ she preferred to order a servant and to ask of a medical man. Undoubtedly she was a crank, but she was likewise a type-a type of the public here which is as yet uneducated as to what nffices and intelligence may be combined in the person of a trained nurse. The public here has much to learn, the nurse who is glad to work for two dollars a day because it is hard on that public to ask more has much to learn, and until the proper ratio of give and take is established between the nurse and the public by means of the physician, nursing here can never be on the same basis as it is with us.

As to the life and the living expenses of the nurse herself: There 
is a very prevalent belief that Italy is an exceedingly cheap country to live in, and from the householder's point of view this probably is true, but to a nurse, an individual unit to whom house-rent, servants' wages, and the food market are of no concern, the difference is not so apparent. The comforts of life, thosc things which to us through long habit have become necessities, are here still regarded as luxuries, and luxuries, judged by whatever standard, are expensive. There are no bathtubs such as we are accustomed to, except in some of the larger pensions and hotels; hot water is a thing that is carried up from the kitchen (usually basement) in tin cans; in many houses lamps and candles are the only source of artificial light, and the Italian idea of what in cold weather constitutes a warm room bears no relation whatever to our conception of one. These things, of course, are all procurable, every one of them, but not if one desires to live cheaply; to obtain them one must pay relatively considerably more than for the same things at home. Street-car fare is two cents, but one can seldom reach one's destination by them, one merely asks which line of "trams" will take one nearest it; for direct transportation one must take a cab, which in themsclves are cheap enough, the fare being only one franc (twenty cents), but evcn cab fare, little enough though it be, amounts to more in the end than five-cent car fare. Washing is really inexpensive, and it is about the only thing for which one gets the cxact equivalent here as at home. A good, liberal week's wash, including six or seven aprons and as many collars and pairs of cuffs and a couple of uniforms, comes to something under a dollar, and is beautifully done too. Clothing - that is, dress material-costs little if one knows how to buy it, and the making of it is very inexpensive too if one knows how to find a cheap little dressmaker, but this, unfortunately, one cannot do unless one has a friend who lives here and is thoroughly familiar with all the intricacies of "bargaining." Alone, one would be able to buy clothes and have them made on little if any better terms than in America, for over here all Americans are supposed to be rich, and to the shopkeeper they are his natural and legitimate victims.

As to languages, English will carry one through very well provided one keeps close to the beaten track and no emergencies arise. French is very, very useful, a necessity almost, as nearly all Italians speak it, from the shopkeepers down to the hotel chambermaids and cabmen, and even if one has only a little of it at command, it will prove of untold value. As to Italian, one can get on perfectly well with the hotel servants, etc., by knowing just a few needful words or phrases for such common things as "hot water," "milk," "eggs," etc. Helped out by plentiful gesticulation, it is surprising to see how far and how well one can get along in this elementary fashion, though I must say I was con- 
siderably surprised one day when my patient had been ordered to take his first drive one afternoon and I had ordered a carriage at four, to find that the order had been construed into mcaning a carriage and four, and that they were hunting the town over to get a four-horse coach at such a short notice! A little dictionary is a good thing to have, since in a tight place one can point out one's wants, but dictionaries are rather treacherous, as they are apt to fail one in a crisis by leaving out the right word. Phrase books are abominations-a laboriously pronounecd ten-word sentence generally brings forth a fifty-word reply which defies comprchension!

Nursing at a hotel or pension is usually very nicc; the cases arc, as a rule, acute, and the joy of a sick traveller whon amidst all the strangeness of foreign life, foreign food, and foreign tongues he rcalizes that he has a genuine American nurse to take care of him is something good to behold. One wears uniform when on duty, and the meals are scrved in one's room, which does away with the long absence from the patient during the prolonged and tedious table d'hôte lunches and dinners, which last usually for an hour and sometimes longer.

The hours off duty or betwcen cases I shall makc no effort to describe. They are the hours that make everything worth while-they are the hours for which one comes abroad!

\section{aras}

Sublimate in Puerperal Infection.-The Journal of the American Medical Association has an abstract of an article in an Italian contemporary, Gazetta degli Ospedali, as follows: "Fabio describes a case of severe puerperal infeetion, apparently in the last stages when first seen. He injected intravenously three milligrams of a one per thousand solution of sublimate, with local measures. The tcmperaturc declined a little the same evening and there was slight abatcment of the symptoms. Six intravenous injections wcre thus made in the course of a week, after which the paticnt was soon rcstored to health, an extensive ulecration of a laceration of the vagina having healed completely." [Bidoli has recently published a similar ease of reeovery under sublimate as a last resource (Policlinico, July 9). The patient was apparently moribund.-ED.] mercury chloride 